\title{
Build and test a novel low heat leak fundamental power coupler
}

\section{Cooperative Research and Development Agreement Final Report}

\section{CRADA Number: FRA-2015-0078}

\section{Fermilab Technical Contact: Sergey Kazakov}

Summary Report

1 July 2019 


\section{NOTICE}

This report was prepared as an account of work sponsored by an agency of the United States government. Neither the United States government nor any agency thereof, nor any of their employees, makes any warranty, express or implied, or assumes any legal liability or responsibility for the accuracy, completeness, or usefulness of any information, apparatus, product, or process disclosed, or represents that its use would not infringe privately owned rights. Reference herein to any specific commercial product, process, or service by trade name, trademark, manufacturer, or otherwise does not necessarily constitute or imply its endorsement, recommendation, or favoring by the United States government or any agency thereof. The views and opinions of authors expressed herein do not necessarily state or reflect those of the United States government or any agency thereof.

Available electronically at http://www.osti.gov/bridge

Available for a processing fee to U.S. Department of Energy and its contractors, in paper, from: U.S. Department of Energy Office of Scientific and Technical Information P.O. Box 62

Oak Ridge, TN 37831-0062 phone: 865.576 .8401

fax: 865.576 .5728

email: mailto:reports@adonis.osti.gov

Available for sale to the public, in paper, from:

U.S. Department of Commerce

National Technical Information Service 5285 Port Royal Road

Springfield, VA 22161

phone: 800.553 .6847

fax: 703.605.6900

email: orders@ntis.fedworld.gov

online ordering: http://www.ntis.gov/ordering.htm 
In accordance with Requirements set forth in Article X.A(2) of the CRADA document, this document is the final CRADA report, including a list of Subject Inventions, to be forwarded to the Office of Science and Technical Information as part of the commitment to the public to demonstrate results of federally funded research.

CRADA number: $\quad$ FRA-2015-0078

CRADA Title: $\quad$ Build and test a novel low heat leak fundamental power coupler

Parties to the Agreement: Euclid TechLabs and Fermi Research Alliance, LLC

\begin{abstract}
CRADA work:
Fermi National Accelerator Laboratory and Euclid Techlabs propose to build and test prototypes of a new RF power coupler. The prototype solves reliability problems associated with present power couplers, which may lead to increased up-time of national laboratory accelerators for scientific users, as well as encourage development of industrial, medical, and security accelerator applications. The goal of the proposed project is to build and test a prototype of a proprietary coupler developed by Fermilab. The prototype will permit evaluation of reliability and low cryogenic heat leak in subsequent testing under a follow-on to this pilot program. The prototype design will be fabricated at Euclid Techlabs and tested at Fermilab using existing 1.3 GHz RF infrastructure.
\end{abstract}

\title{
Summary of Research Results:
}

A reliable coupler design with no copper plating was developed. Coupled electromagneticthermomechanical simulations were used in optimization studies that resulted in an extremely low (less than $1 \mathrm{~W}$ ) power flow to a cold cavity at $250 \mathrm{~kW}$ of CW RF power at $650 \mathrm{MHz}$. A full 3D engineering design was also developed, meaning that the coupler is ready for manufacturing.

\section{Related Reports, Publications, and Presentations:}

SRF2015 Presentation by R. Kephart

Subject Inventions listing:

None

Report Date: 1 Jully 2019

Technical Contact at Fermilab: Sergey Kazakov

This document contains NO confidential, protectable or proprietary information. 